\begin{tabular}{|c|c|c|c|c|}
\hline $\begin{array}{c}\text { Jurnal Penelitian \& } \\
\text { PPM }\end{array}$ & ISSN: 2442-448X & Vol 4, No: 2 & Hal: $129-389$ & Juli 2017 \\
\hline
\end{tabular}

\title{
FENOMENA "NGELEM" OLEH ANAK JALANAN DI KOTA MAKASSAR
}

\author{
OLEH : \\ AZHARY ADHYN ACHMAD, NANDANG MULYANA, MUHAMMAD FEDRYANSYAH
}

\begin{abstract}
Abstrak
Perkembangan suatu wilayah akan selalu diikuti dengan berbagai masalah. Hal ini terjadi karena perkembangan wilayah akan diikuti dengan adanya perubahan social dalam masyarakat. Tidak seтиа perubahan social yang terjadi sesuai dengan yang direncanakan. Akibatnya muncul dampak perubahan social yang merupakan masalah social. Masalah social yang paling sering terlihat di kota besaar adalah kehadiran anak jalanan. Kehadiran anak jalanan ini sebagai dampak dari perubahan social yang terjadi.

Kehadiran anak jalanan akan diikuti dengan adanya masalah social lainnya yaitu perilaku bebas dari anak jalanan tersebut. Saah satu perilaku bebas tersebut adalah perilaku "ngelem" yang dilakukan oleh anak jalanan. Perilaku "ngelem" ini mempunyai dampak yang tidak baik bagi anak jalanan. Dampaknya tidak hanya bersifat fisik saja tetapi juga bersifat psikologis dan social.

Untuk mengatasi permasalahan perilaku "ngelem yang dilakukan oleh anak jalan tidak hanya dilakukan intervensi yang bersifat represif saja. Diperlukan juga intervensi yang bersifat preventif. Selain itu intervensi tidak hanya dilakukan pada masalah yang terjadi saat ini juga dilakukan pada factor penyebab dan ddampak dari masalah tersebut.

Kata kunci : perubahan social, anak jalanan, dan intervensi
\end{abstract}

\section{Pendahuluan}

Fenomena anak jalanan semakin mengkhawatirkan. Anak jalanan merupakan anak-anak yang menghabiskan waktunya di jalanan untuk bekerja dan bersosialisasi dengan orang lain. Data UNICEF pada tahun 2008 terdapat 100 juta anak jalanan di dunia. Di Indonesia, berdasarkan data dari pusat data dan informasi kesejahteraan sosial Kementerian Sosial RI, jumlah anak jalanan mengalami tren menurun. Pada tahun 2006 sebanyak 232.894 anak, pada tahun 2010 sebanyak 159.230 anak, tahun 2011 sebanyak 67.607 anak, dan tahun 2015 sebanyak 33.400 anak. Penurunan jumlah ini tidak serta merta fenomena anak jalanan berkurang. Penurunan angka anak jalanan ini diiringi dengan semakin bertambahnya masalah yang dialami oleh anak jalanan.

Kota Makassar juga mengalami fenomena anak jalannan ini. Data Dinas Sosial Kota Makassar, menyebutkan bahwa pada tahun 2016 ini jumlah anak jalanan di Makassar meningkat menjadi 1.000 orang, dari tahun-tahun sebelumnya yang berkisar 500 orang. Keberadaan anak jalanan di Kota Makassar terfokus pada beberapa titik seperti dipertokoan dan mall, serta perempatan jalan.

Jika ditelusuri secara mendalam, fenomena anak jalanan secara garis besar sebagai akibat dari dua hal mendasar, yang pertama adalah problema psikososial, yaitu hubungan antara orang tua dan anak tidak 
harmonis. Orang tua kurang peduli dan kurang perhatian kepada anak-anaknya sehingga anak mencari perhatian di luar rumah, yakni jalanan sebagai bentuk pelarian atau kompensasinya. Kedua, problema sosial ekonomi yang didominasi oleh masalah kemiskinan dan kebodohan, sehingga banyak orang tua atau keluarga yang tidak mampu menyediakan kebutuhan dasar anak termasuk kebutuhan untuk mendapatkan pendidikan secara layak. Kurang atau tidak tersedianya fasilitas bermain bagi anak-anak di tempat tinggal mereka yang kumuh.

Kebanyakan anak jalanan ini mencari makan dengan jalan sebagai pengamen, pengemis, pedagang asongan, penjual koran bahkan ada sebagian yang berlaku sebagai preman. Mereka bekerja dari siang hingga malam hari. Hal ini tentu saja merupakan kondisi yang memprihatinkan mengingat jam kerja yang lumayan panjang sehingga gangguan kesehatan yang rentan terjadi dan ancaman kejahatan seperti pemalakan. Selain itu dengan hidup bebas yang dijalaninya, anak jalanan juga rentan terhadap penggunaan narkoba..

Mengingat harga narkoba yang tidak terjangkau, sebagai alternatif anak jalanan menggunakan zat adiktif untuk memenuhi kebutuhan anak narkobanya. Zat adiktif yang paling sering digunakan oleh anak jalanan itu adalah lem aibon yang dihirup seperti halnya dengan beberapa jenis narkotika tertentu. Perbuatan ini disebut Inhalen. Inhalen adalah dimana seseorang menghirup uap dari zat pelarut (thinner cat), uap lem, atau zat lainnya yang dapat membuat mabuk. Inhalen sendiri adalah senyawa organik berupa gas pelarut yang mudah menguap. Senyawa ini biasa ditemukan dalam zat - zat yang mudah ditemukan anak - anak dan remaja seperti lem aica aibon, pelarut cat, tip-ex, bensin, pernis, aseton, dan sebagainya. Dengan harga yang cukup murah dan dijual secara bebas, maka produk yang mengandung inhalen menjadi semacam narkotika yang mudah didapatkan.
Kebiasaan untuk menghirup lem atau sering disebut "ngelem" merupakan salah satu cara untuk menghilangkan stress. Selain itu kebiasaan untuk "ngelem juga dipengaruhi oleh teman-teman yang lain sebagai bentuk dari solidaritas diantara anak-anak jalanan. "ngelem" juga seringkali dijadikan syarat untuk diterima dalam pergaulan ataupun komunitas tertentu.

Bahaya yang diakibatkan dari "nglem" ini dapat bermacam-macam dan terkadang pecandunya kebanyakan tidak mengetahui organ tubuh mana saja yang dapat terserang. Bahayanya tidak hanya menyerang organ tubuh seperti otak, jantung dan paru-paru, bahkan virus pun akan lebih mudah masuk kedalam tubuh mereka. Tidak hanya menyerang fisik, melainkan mental, emosional dan spiritual mereka pun akan terganggu.

\section{Tinjauan Konseptual}

\section{Analisis terhadap Anak Jalanan}

\section{a. Definisi Anak Jalanan}

Anak jalanan adalah istilah yang sudah sangat akrab bagi kita. UNICEF mendefenisikan tentang anak jalanan adalah : Street child are those who have abandoned their homes, school and immediate communities before they are sixteen years of age, and have drifted into a nomadic street life (anak jalanan merupakan anak-anak berumur dibawah 16 tahun yang sudah melepaskan diri dari keluarga, sekolah dan lingkungan masyarakat terdekatnya, larut dalam kehidupan yang berpindah-pindah di jalan raya (H.A Soedijar, 1988:16).

Menurut Departemen Sosial Republik Indonesia (2005:5) defenisi anak jalanan adalah anak yang menghabiskan sebagian besar waktunya untuk melakukan kegiatan hidup sehari-hari di jalanan baik untuk mencari nafkah atau berkeliaran di jalanan dan tempattempat umum lainnya. 


\section{b. Jenis Anak Jalanan}

Surbakti dkk. (1997), ada tiga kategori anak jalanan, yaitu children on the street, children of the street dan children in the street atau sering disebut juga children from families of the street. Pengertian untuk children on the street adalah anak-anak yang mempunyai kegiatan ekonomi di jalanan yang masih memiliki hubungan dengan keluarga. Ada dua kelompok anak jalanan dalam kategori children on the street, yaitu anak-anak yang tinggal bersama orang tuanya dan senantiasa pulang ke rumah setiap hari, dan anak-anak yang melakukan kegiatan ekonomi dan tinggal di jalanan namun masih mempertahankan hubungan dengan keluarga dengan cara pulang baik berkala ataupun dengan jadwal yang tidak rutin.

Children of the street adalah anak-anak yang menghabiskan seluruh atau sebagian besar waktunya di jalanan dan tidak memiliki hubungan atau ia memutuskan hubungan dengan orang tua atau keluarganya. Children in the street atau children from the families of the street adalah anak-anak yang menghabiskan seluruh waktunya di jalanan yang berasal dari keluarga yang hidup atau tinggalnya juga di jalanan.

\section{Tinjauan terhadap Lem sebagai Zat Adikitf}

Lem adalah sejenis bahan serbaguna, untuk merekatkan berbagai alat atau barang. Lem ini berguna untuk merekatkan barang dari bahan kulit binatang (tas, sepatu), plastik, kayu, kertas, aluminium, karet, tembaga, besi dan lain-lain. Jenis lem ini sering disalahgunakan oleh anak-anak jalanan untuk membuat mereka mabuk karena lem ini termasuk kategori zat adiktif yang berbahaya.

Zat yang ada dalam lem adalah zat kimia yang bisa merusak sel-sel otak dan membuat kita menjadi tidak normal, sakit bahkan bisa meninggal. Salah satu zat yang terdapat di dalam lem adalah Lysergic Acid Diethyilamide (LSD). Lysergic acid diethylamide (LSD) adalah halusinogen yang paling terkenal. Ini adalah narkoba sintetis yang disarikan dari jamur kering (dikenal sebagai ergot) yang tumbuh pada rumput gandum. LSD adalah cairan tawar, yang tidak berwarna dan tidak berbau yang sering diserap ke dalam zat yang cocok seperti kertas pengisap dan gula blok, atau dapat dipadukan dalam tablet, kapsul atau kadang-kadang gula-gula. Bentuk $L S D$ yang paling popular adalah kertas pengisap yang terbagi menjadi persegi dan dipakai dengan cara ditelan.

Untuk penggunaan $L S D$ efeknya dapat menjadi nikmat yang luar biasa, sangat tenang dan mendorong perasaan nyaman. Sering kali ada perubahan pada persepsi, pada penglihatan, suara, penciuman, perasaan dan tempat. Efek negatif $L S D$ dapat termasuk hilangnya kendali emosi, disorientasi, depresi, kepeningan, perasaan panik yang akut dan perasaan tak terkalahkan, yang dapat mengakibatkan pengguna menempatkan diri dalam bahaya fisik.

Pengguna jangka panjang dapat mengakibatkan sorot balik pada efek halusinogenik, yang dapat terjadi berhari- hari, berminggu-minggu atau bahkan berbulanbulan setelah memakai $L S D$. Tidak ada bukti atau adanya ketergantungan fisik dan tidak ada gejala putus zat yang telah diamati bahkan setelah dipakai secara berkesinambungan. namun, ketergantungan kejiwaan dapat terjadi. Efek $L S D$ normalnya 6-12 jam setelah menggunakan, tergantung pada dosis, toleransi, berat badan dan umur. Keberadaan $L S D$ tidak lebih lama keberadaannya daripada obat-obat dengan level signifikan di dalam darah.

\section{Metode}

Kajian ini menggunakan data sekunder yang didasarkan kepada studi dokumentasi dan pustaka. Studi dokumentasi lebih diarahkan untuk mengkaji dan menganalisis hasil laporan serta data yang telah dipublikasikan yang berkaitan dengan fenomena yang dikaji. 
Sementara itu studi pustaka lebih diarahkan untuk menganlisis fenomena yang ada didasarkan kepada konsep atau teori yang sesuai dengan fenomena yang dikaji

\section{Hasil Penelitian}

\section{Faktor-faktor Penyebab Anak Jalanan "ngelem"}

Lem fox dan aibon merupakan jenis lem yang paling banyak digunakan oleh anak jalanan di Kota Mkasaar untuk "ngelem". Lem ini merupakan zat adiktif berbahaya yang sangat mudah didapat karena keberadaannya yang legal. Hal ini yang menyebabkan penyalahgunaan pemakaian lem ini sangat cepat perkembangannya terutama di dunia anak jalanan. Jika kita sering melihat anakanak jalanan yang sedang memasukkan salah satu tangannya ke dalam baju, serta mendekatkannya ke hidung, berarti anak tersebut sedang menghirup lem fox dan aibon.

Zat adiktif adalah zat-zat kimiawi yang dimasukkan ke dalam tubuh manusia, baik ditelan melalui mulut, dihirup melalui hidung maupun disuntikkan melalui urat darah. Zatzat kimia itu dapat mengubah pikiran suasana hati atau perasaan, dan perilaku seseorang. Pemakaian terus menerus akan mengakibatkan ketergantungan fisik dan atau psikologis. Resiko yang pasti terjadi adalah kerusakan pada sistem syaraf dan organ-organ penting lainnya seperti jantung, paru-paru, dan hati.

Keberadaan anak-anak yang sedang teler akibat "ngelem" ini dapat dijumpai di bawah jembatan, pojokan-pojokan perempatan lampu merah. Anak-anak yang cenderung tidak tahu akibat negatif dari kegiatan "ngelem" ini. Anak jalanan hanya mengetahui bahwa mereka merasa senang setelah menggunakannya. Sesaat setelah pemakaian mereka akan merasa "fly", happy, bebas dari masalah mereka.

Kemiskinan merupakan factor utama anak jalanan untuk terjun ke jalan. Kehidupan yang keras dijalan inilah yang nendorong anak jalanan untuk melakukan kegiatan "ngelem". Kegiatan "ngelem" merupakan sarana bagi anak jalanan untuk menghilangkan stress yang diderita selama hidup di jalanan. Factor lainnya yang menjadi penyebab anak jalanan untuk "ngelem" adalah sebagai bentuk solidaritas. Kegiatan "ngelem" yang dilakukan oleh teman-temannya mendorong anak jalanan yang lain untuk ikut terlibat dalam kegiatan "ngelem tersebut. Dengan demikian kegiatan "ngelem" yang dilakukan juga sebagai sarana untuk diterima dalam suatu pergaulan dalam komunitas anak jalanan.

Kegiatan :ngelem" juga dipengaruhi oleh factor keinginan untuk mendapatkan perhatian lebih dari pihak lain baik itu teman sesama anak jalanan maupun orang lain dalam masyarakat. Keinginan untuk diperhatikan ini berhubungan dengan anggapan bahwa anak jalanan merupakan komunitas yang tidak "berguna" serta diremehkan oleh masyarakat. Kondisi inilah yang selanjutnya mendorong anak jalanan untuk mencari "kekuasaan" lewat "ngelem". Dalam kondisi mabuk lem inilah anak jalanan data memperlihatkan eksistensi dirinya terhadap pihak lain.

Sebagaimana dalam teorinya Sutherland, yang dikenal dengan assosiasi diffrensial menyatakan bahwa perilaku termasuk perilaku jahat merupakan suatu perbuatan dari proses belajar. Demikian juga dengan anak jalanan yang "ngelem" pada umumnya disebabkan karena belajar dari lingkungannya melalui suatu proses interaksi dalam pergaulan yang akrab. Dengan kata lain, anak yang memakai lem fox dan aibon terlibat dalam suatu interaksi yang akrab dengan orang-orang yang ada di sekitar lingkungannya.

\section{Intervensi terhadap Perilaku "ngelem" Anak jalanan di Kota Makassar}

Anak jalanan merupakan fenomena yang menjadi masalah bagi kota besar ternasuk Kota Makassar. Kehadiran anak jalanan di Kota Makassar dengan perilaku "ngelem" 
menjadi masalah baru yang perlu mendapatkan perhatian dari semua pihak. Intervensi yang dilakukan tidak hanya terhadap masalah yang ada saat ini yaitu keberadaan anak jalanan dan perilaku "ngelem" yang dilakukan oleh anak jalanan. Intervensi juga harus dilakukan terhadap factor penyebab semakin maraknya anak jalanan di Kota Makassar. Selain itu juga perlu intervensi terhadap perilaku "ngelem" yang dilakukan oleh anak jalanan. Kemudian intervensi juga dilakukan terhadap dampak yang mungkin ditimbulkan karena keberadaan dari anak jalanan tersebut termasuk dampak dari perilaku "ngelem" yang dilakukan oleh anak jalanan. Berikut ini beberapa intervensi yang dapat dilakukan untuk mengetasi anak jalanan serta perilaku "ngelem" dari anak jalanan.

Upaya preventif yang telah dilakukan Polrestabes Makassar adalah dengan bekerja sama dengan pihak Badan Narkotika Nasional Kota Makassar untuk memberikan sebatas edukasi atau memberikan pencerahan dengan mengadakan penyuluhan tentang bahaya narkoba dan zat adiktif di beberapa sekolah yang ada di kota Makassar dan juga pengawasan serta pemahaman tentang bagaimana cara memproteksi anak dengan agama dan pendidikan, sejalan dengan visi misinya yakni menciptakan generasi muda yang baik melalui pemberdayaan sumber daya manusia.

Upaya preventif yang dilakukan oleh Pihak Polrestabes Makassar dibantu oleh Satuan Polisi Pamong Praja adalah dengan melakukan pengawasan di daerah-daerah yang dianggap rawan terhadap perilaku "ngelem" yang dilakukan oleh anak jalanan perlu dilakukan patroli rutin, kemudian melakukan razia di tempat atau di jalan-jalan yang dianggap rawan terkait dengan masalah tersebut sehingga mampu meminimalisir atau bahkan dihentikan terkait dengan masalah penyalahgunaan lem fox dan aibon.

Upaya represif ini sebenarnya tidak begitu diharapkan dalam kasus ini dikarenakan ketidakberhasilan upaya pre-emtif dan preventif dalam mencegah terjadinya penyimpangan tersebut sebab upaya ini merupakan upaya setelah terjadinya penyimpangan, yang mana dari pihak Badan Narkotika Nasional Provinsi Sulawesi Selatan itu sendiri didukung oleh Pemerintah Kota telah menyediakan panti rehabilitasi yang mana terletak di Badoka, Jalan Perintis Kemerdekaan Makassar yang digunakan untuk pemulihan keadaan bagi pengguna narkotika dan zat adiktif lainnya termasuk pula bagi para anak jalanan pemakai lem aibon yang besar harapan sekeluar dari panti rehabilitasi tersebut mampu kembali produktif dan mampu hidup bersosialisasi dengan masyarakat.

\section{Penutup}

1. Penyalahgunaan perilaku "ngelem" pada anak jalanan telahmerusak masa depan anak-anak. Kerusakan yang ditimbulkan dari perilaku "ngelem" ini tidak saja berkaitan dengan fisik tetapi juga kerusakn psikis dan social. Perilaku "nglem ini sama bahayanya dengan mengkonsumsi narkotika dan obat-obatan terlarang lainnya.

2. Hendaknya setiap orang termasuk bagi anak jalanan itu sendiri agar dapat mengisi hariharinya dengan mendekatkan diri kepada Tuhan Yang Maha Esa dan kegiatankegiatan lain yang bersifat positif.

3. Kepada masing-maisng orang tua, guru, dan masyarakat sebaiknya selalu memberikan arahan-arahan yang bersifat positif untuk menghindari bahaya zat adiktif berbahaya bagi generasi muda.

4. Oleh karena itu cara termudah untuk mencegah dampak buruk dari penggunaan zat adiktif yang berbahaya tersebut adalah tidak mulai menggunakannya sama sekali, karena sekali pemakai kecanduan, ia akan memiliki ketergantungan fisik dan psikologis yang bisa berlangsung seumur hidup. 


\begin{tabular}{|c|c|c|c|c|}
\hline $\begin{array}{c}\text { Jurnal Penelitian \& } \\
\text { PPM }\end{array}$ & ISSN: 2442-448X & Vol 4, No: 2 & Hal: $129-389$ & Juli 2017 \\
\hline
\end{tabular}

\section{DAFTAR PUSTAKA}

Goudzweed Bob \& Harry De Lange. Dibalik Kemiskinan \& kemakmuran. Yogyakarta; Penerbit Kanisius. 1998.

Kartono. Kartini. Kenakalan Remaja. PT. Raja Grafindo Persada. Jakarta; 2010.

Makarao, Taufik, dkk: 2003. Tindak Pidana Narkotika. Jakarta. Penerbit Ghalia Indonesia.

M. Sihombing, Justin. Kekerasan Terhadap Masyarakat Marjinal. Penerbit Yogyakarta; Narasi. 2005.

Naning, Ramdlon. Problema Gelandangan Dalam Tinjauan Tokoh Pendidikan dan Psikologi. Bandung; Penerbit Armico. 1982.
Sasangka Hari. Narkotika dan Psikotropika Dalam Hukum Pidana, Bandung; Mandar Maju, 2003.

Siregar, Bismar dkk. Hukum dan Hak-Hak Anak. Jakarta; Yayasan LBH Indonesia dan CV Rajawali. 1986.

Sojono, AR, Bony Daniel. Komentar dan Pembahasan UU no. 35 Tahun 2009 Tentang Narkotika. Jakarta; Penerbit Sinar Grafika. 2011.

Suyanto, Bagong. Masalah Sosial Anak. Jakarta; Kencana. 2010.

S. Willis, Sofyan. Problema Remaja \& Permasalahannya. Bandung; Penerbit Angkasa. 1981. 